\title{
40-year long-term study of microbial parameters near Helgoland (German Bight, North Sea): historical view and future perspectives
}

Received: 11 November 2003 / Revised: 20 April 2004 / Accepted: 10 July 2004 / Published online: 1 October 2004 (C) Springer-Verlag and AWI 2004

\begin{abstract}
Since 1873, the waters at Helgoland Roads (sampling station "Kabeltonne") have been sampled daily to determine temperature and salinity. In 1962, microbiological parameters were determined for the first time to establish microbiological long-term studies on marine bacteria, starting with the colony-forming units (CFU). In the following years, several other microbiological parameters were integrated for different periods of time (e.g. activity parameters like ATP and ectoenzymatic activity, marine yeasts, oil-degrading bacteria, flagellates and molecular methods like PCR followed by denaturing gradient gel electrophoresis). To date, the total count of bacteria, flagellates and viruses have been acquired using fluorescent DNA dyes and epifluorescence microscopy. Here we present both a historical overview of the methods used and examples of results obtained over the past 40 years. Furthermore, we try to evaluate challenging new methods for marine microbial ecology, appropriate for long-term studies of marine bacteria.
\end{abstract}

Keywords Marine bacteria - Long-term studies · Bacterial diversity $\cdot$ Seasonal succession

\section{Introduction}

Viewing the 40 years of long-term marine bacteria studies at the sampling station "Kabeltonne" near Helgoland provides us with an image of the development of methods in microbial oceanography over the last four decades.

Communicated by K. Wiltshire

G. Gerdts $(\bullet) \cdot$ A. Wichels · H. Döpke $\cdot$ K.-W. Klings · C. Schütt Alfred-Wegener-Institut für Polar- und Meeresforschung,

Biologische Anstalt Helgoland,

27483 Helgoland, Germany

e-mail: ggerdts@awi-bremerhaven.de

Tel.: +49-4725-819245

Fax: +49-4725-819283

W. Gunkel

25488 Holm, Germany
Starting with the determination of colony-forming units in 1962, new methods were introduced every few years. However, most techniques were replaced after a few years (see Table 1). After the determination of the biological oxygen demand (BOD) was introduced in 1965, measurements of surface tension were added in 1972. In the 1980 s, the number of marine yeasts, luminescent bacteria and oil-degrading bacteria were determined and total organic carbon (TOC) was measured. A major improvement was the introduction of epifluorescence microscopy for total bacterial counts and flagellates (AODC and F-DC) in 1987. Activity parameters such as the determination of bacterial ATP and ectoenzymatic activity were introduced in 1989 and 1995, respectively. The first molecular technique integrated into the long-term studies on marine bacteria was PCR-DGGE, used to survey bacterial diversity and seasonal succession, in 1996. Another method introduced in 1996 was the determination of total bacterial counts by flowcytometry (FBC). The microscopic counting of virus-like particles started in 2000. From the literature, however, only a few of these methods are still in general use. Hence, for the long-term studies at sampling station "Kabeltonne", the only parameters which have been continuously acquired until today are AODC, F-DC and total virus count (VLP-DC).

This is an attempt to evaluate the results from a historical point of view, and also considering the knowledge acquired by the scientific community during the last 15 years.

\section{Methods}

Sampling

Samples were collected weekly from 1-m depth or from the neuston at the location "Kabeltonne" between the island of Helgoland and the adjacent dune island by the research boats Ellenbogen or Aade. For incubation experiments and cultivation of bacteria, samples were taken aseptically using a sterile ZoBell sampler. Neuston samples were taken with a fly-screen. Table 1 shows the recorded parameters and the corresponding sampling periods. 
Table 1 Overview of the parameters acquired from the Microbiology Department of the Biologische Anstalt Helgoland at the sampling station "Kabeltonne", Helgoland Roads from 1962 until today. Samples were mostly taken at weekly intervals. $A O D C$ acridine orange direct counting; $B O D$ biological oxygen demand; $C F U$ colonyforming units; $D G G E$ denaturing gradient gel electrophoresis; $F-D C$ flagellates direct counting; $F B C$ flowcytometric bacterial counts; $O D B$ oil-degrading bacteria; TOC total organic carbon; $V L P-D C$ virus-like particles direct counting

\begin{tabular}{|c|c|c|c|c|c|c|}
\hline \multirow{2}{*}{$\frac{\text { Parameter }}{\text { AODC }}$} & \multicolumn{3}{|l|}{ Sample } & \multicolumn{2}{|c|}{ Sampling period } & \multirow{2}{*}{$\frac{\text { See Fig. }}{1,2,3,4,5,6,7}$} \\
\hline & Pelagic & & & Jan 1987 & now & \\
\hline & Neuston & & & Jan 1987 & June 1993 & \\
\hline F-DC & $1 \mathrm{~m}$ & & & Jan 1990 & now & 6 \\
\hline VLP-DC & $1 \mathrm{~m}$ & & & Jan 2000 & now & 1,3 \\
\hline $\mathrm{FBC}$ & $1 \mathrm{~m}$ & & & June 1996 & July 1998 & 1,3 \\
\hline \multirow[t]{10}{*}{ CFU } & $1 \mathrm{~m}$ & pouring & 2216EM & Jan 1962 & Dec 1995 & \\
\hline & $1 \mathrm{~m}$ & plate & 2216ES & May 1963 & June 1993 & \\
\hline & Neuston & technique & 2216EM & Aug 1973 & Dec 1995 & \\
\hline & Neuston & & 2216ES & Aug 1973 & Dec 1995 & \\
\hline & $1 \mathrm{~m}$ & spread & 2216EM & June 1993 & Apr 2000 & 6 \\
\hline & $1 \mathrm{~m}$ & plate & $2216 \mathrm{ES}$ & June 1993 & Apr 2000 & \\
\hline & $1 \mathrm{~m}$ & technique & $1 / 102216 \mathrm{EM}$ & June 1993 & Apr 2000 & \\
\hline & $1 \mathrm{~m}$ & & 1/10 2216ES & June 1993 & Apr 2000 & \\
\hline & $1 \mathrm{~m}$ & & $2216 \mathrm{EM}-\mathrm{CdCl}_{2}$ & June 1993 & Dec 1995 & \\
\hline & $1 \mathrm{~m}$ & & $2216 \mathrm{EM}-\mathrm{HgCl}_{2}$ & June 1993 & Dec 1995 & \\
\hline \multirow[t]{2}{*}{ Yeasts } & $1 \mathrm{~m}$ & & & Jan 1966 & Dec 1971 & \\
\hline & & & & Jan 1980 & Dec 1992 & 11 \\
\hline $\begin{array}{l}\text { Luminescent } \\
\text { bacteria }\end{array}$ & $1 \mathrm{~m}$ & & & Jan 1981 & Dec 1983 & \\
\hline \multirow[t]{2}{*}{ ODB } & $1 \mathrm{~m}$ & & & Jan 1965 & Dec 1967 & \\
\hline & & & & Jan 1980 & June 1993 & 9 \\
\hline BOD & $1 \mathrm{~m}$ & & & Jan 1965 & June 1993 & 10 \\
\hline Surface & Neuston & & & Apr 1972 & Oct 1992 & \\
\hline tension & $1 \mathrm{~m}$ & & & Apr 1972 & Oct 1992 & \\
\hline \multirow[t]{2}{*}{ ATP } & Neuston & & & Dec 1989 & May 1993 & \\
\hline & $1 \mathrm{~m}$ & & & Dec 1989 & May 1993 & 7 \\
\hline \multirow[t]{2}{*}{ TOC } & Neuston & & & Jan 1980 & Dec 1984 & \\
\hline & $1 \mathrm{~m}$ & & & Jan 1980 & Dec 1984 & \\
\hline $\begin{array}{l}\text { Ectoenzymatic } \\
\text { activity }\end{array}$ & $1 \mathrm{~m}$ & & & Jan 1995 & Oct 1996 & 8 \\
\hline \multirow[t]{2}{*}{ PCR-DGGE } & $1 \mathrm{~m}$ & $>3 \mu \mathrm{m}$ & & Aug 1996 & July 1999 & 5 \\
\hline & & \multicolumn{2}{|c|}{$0.2 \mu \mathrm{m}-3 \mu \mathrm{m}$} & Aug 1996 & July 1999 & 5 \\
\hline
\end{tabular}

\section{Direct counts}

Bacteria and flagellate counts (AODC, F-DC) were carried out according to Zimmermann and Meyer-Reil (1974) as modified by Hobbie et al. (1977) using epifluorescence microscopy (Zeiss IM35 with acridine orange filter set). The estimation of bacterial biovolume and conversion in terms of carbon was performed according to Bratbak (1985). Prior to fixation with formalin (1\% final concentration), samples were filtered through $60-$ or $20-\mu$ m nylon mesh to remove large planktonic cells.

Direct counts of virus-like particles (VLP-DC) were performed as described by Hennes and Suttle (1995), modified after Xenopoulus and Bird (1997). After removal of the bacterial fraction (0.15- $\mu \mathrm{m}$ pressure filtration) viruses were collected onto a $0.02-\mu \mathrm{m}$ Anodisc membrane filter and rinsed twice with pre-filtered Nanopure water. Filters were stained with Yo-Pro-1 in the microwave (600 W) for 3-4 min and washed three times with Nanopure water after cooling down to room temperature. Epifluorescence microscopy was used to count viruses stained with Yo-Pro-1. For each sample, $>200$ viruses in 20 randomly selected fields were counted at a magnification of 1,600 using an epifluorescence microscope (Zeiss IM35) equipped with an acridine orange filter set.

Flowcytometric bacterial counts

Formalin-fixed (final concentration 1\%) samples were stained with SYTOX (Molecular probes) according to the manufacturer's instructions. As an internal standard, an aliquot of fluorescent beads (MF-RhB-beads; $2 \mu \mathrm{m}$; Specht $\mathrm{GmbH}$ ) with known concentration was added. Samples were analyzed using an FACSCalibur Flowcytometer (Becton Dickinson) at $488 \mathrm{~nm}$ excitation wavelength and FL1 detection at 530/30 $\mathrm{nm}$. The data were processed using the Paint a Gate Software (Becton Dickinson).
Colony-forming units (CFU)

Water samples were plated on marine broth 2216E (Oppenheimer and ZoBell 1952) using a Spiral Plater (Spiral Systems). For the cultivation of marine yeasts, samples were filtered on $0.45-\mu \mathrm{m}$ membrane filters and the filters laid on top of an agar plate (Fell et al. 1960). The agar plates were incubated for 7 (yeasts) to 21 days $(\mathrm{CFU})$ at $18^{\circ} \mathrm{C}$ in the dark. Bacterial or yeast colonies were counted using a dissection microscope or a magnifying glass.

\section{Adenosine triphosphate}

The adenosine triphosphate (ATP) content of water samples was acquired according to Vosjan and Nieuwland (1987) using a LUMAC Biocounter M2500 and internal spiking with ATP.

\section{Biological oxygen demand}

The measurement of biological oxygen demand (BOD) is best described in Deutsche Einheitsverfahren für Wasser, Abwasser und Schlammuntersuchungen (1983). Samples were incubated for 21 days at $18^{\circ} \mathrm{C}$ in the dark.

\section{Ectoenzymatic activity}

The ectoenzymatic activity (leucine aminopeptidase; LAPase) was measured according to Somville and Billen (1983) and Hoppe (1993). As an experimental extension, additional to the incubation at in situ temperatures, a temperature range from $0^{\circ} \mathrm{C}$ to $20^{\circ} \mathrm{C}$ (in eight steps) was applied by using a thermatron (Christian and Karl 1995). MCA-leucine was used as the artificial substrate. 
Oil-degrading bacteria

The abundance of oil-degrading bacteria was determined by an MPN method according to Gunkel (1973) using crude oil as the carbon source. Samples were incubated for 12 weeks at $18^{\circ} \mathrm{C}$ in the dark.

Bacterial diversity and seasonal succession

Bacterial diversity and seasonal succession was examined by PCR of the 16S-rDNA gene, followed by denaturing gradient gel electrophoresis (DGGE). Natural bacterioplankton was harvested by pressure filtration (5 litres) onto a filter cascade (3-um cellulose nitrate filter, Sartorius, followed by $0.22-\mu \mathrm{m}$ Sterivex GS capsule filter, Millipore). After filtration, the filters were stored frozen $\left(-20^{\circ} \mathrm{C}\right)$. Nucleic acid extraction was performed using the modified protocol of Anderson and McKay (1983), omitting the denaturing $\mathrm{NaOH}$ step. When filters displayed a brownish colour caused by humic acids, PVPP was added (Holben et al. 1988). All DNA extracts served as template DNAs in the PCR. They were finally kept in TE buffer and stored at $-20^{\circ} \mathrm{C}$ until used. Before PCR amplification, the DNA extracts were analyzed using agarose gel electrophoresis. A part of the $16 \mathrm{~S}$ rDNA (V3 region) was amplified using primers P2/P3 according to Muyzer et al. (1993). The amplification of PCR products of the proper size (233 bp) was confirmed by electrophoresis through a $1.4 \%$ agarose gel. DGGE was performed with a DCODE system (Bio-Rad) according to Muyzer et al. (1993). PCR products of P2/P3 were applied on 6\% (weight/ volume) polyacrylamide (Appligene) gels in $0.5 \times$ TAE buffer with denaturing gradients of $15 \%-55 \%$ urea/formamide. The electrophoresis was run at $60^{\circ} \mathrm{C}$ and $140 \mathrm{~V}$ for $3 \mathrm{~h}$. After electrophoresis, the gels were removed from the glass plates, soaked for $15 \mathrm{~min}$ in Nanopure water containing ethidium bromide $\left(0.5 \mathrm{mg} \mathrm{l}^{-1}\right)$, rinsed in Nanopure water overnight $(12 \mathrm{~h})$, and photographed with UVtransillumination (302 nm) using Polaroid MP4 equipment. Photographs were electronically digitized using a Linotype Saphir Ultra 2 scanner and Adobe Photoshop software.

\section{Results and discussion}

Direct counts and flowcytometric measurements

On the basis of all AODC data sampled over 16 years, the bacterial counts show a continuous increase during each year until reaching a plateau in July and August, followed by a decrease until the end of the year. Bacterial counts from neuston samples displayed an earlier climax (in June). On average, bacterial counts from the winter months November, December, January and February reached only $25 \%$ of the value calculated for the summer period June, July, August and September. Although the arithmetic average of neuston bacterial counts is $77 \%$ of the AODC of samples taken from 1-m depth, peak intensities exceed those from 1-m depth. Fig. 1 shows the bacterial counts from neuston and 1-m depth samples from the introduction of the direct counting method at Helgoland in 1988 until today (neuston until June 1993). Although the principal character of the yearly AODC curves is similar, during the summer months different and varying peaks occur. This presumably indicates different bacterial populations (see below). In principal, bacterial counts are positively correlated with the water temperature with a calculated slope of $\sim 60,000$ bacteria ${ }^{\circ} \mathrm{C}^{-1}$ (Fig. 2). The medians of monthly combined data from January to July can be fitted significantly to a sigmoidal model or from January to May to an exponential model. Based on the assumption of exponential growth at least from April to May, the generation time for the total bacterial population was calculated as 1.13 months. The calculated lag/log turning point is in March (sigmoidal model), while the stationary/decline phase has already started in June/July. While the combined monthly data rather represent the total bacterial biomass, it is still uncertain whether the observed peaks overlaying the general
Fig. 1 Abundance of bacteria and virus-like particles from 1988 to 2003. $A O D C$ acridine orange direct counting, $F B C$ flowcytometric bacterial counts, $V L P-D C$ virus-like particles direct counting

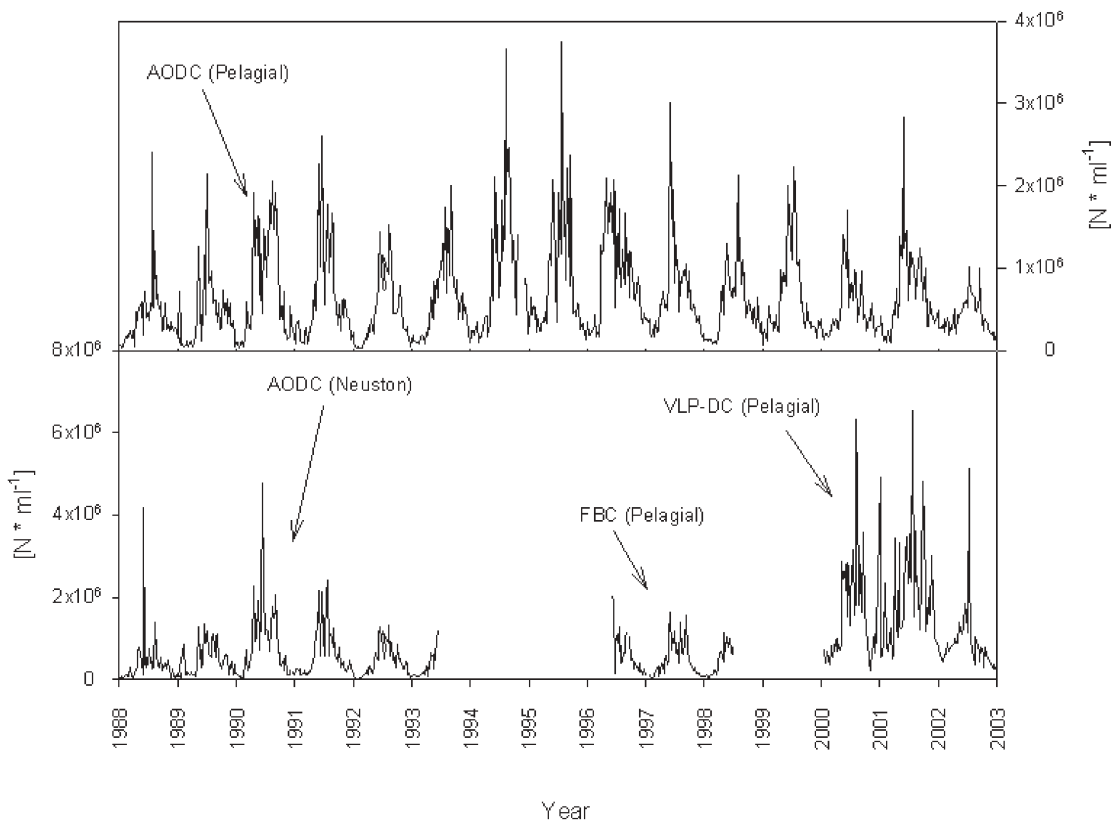




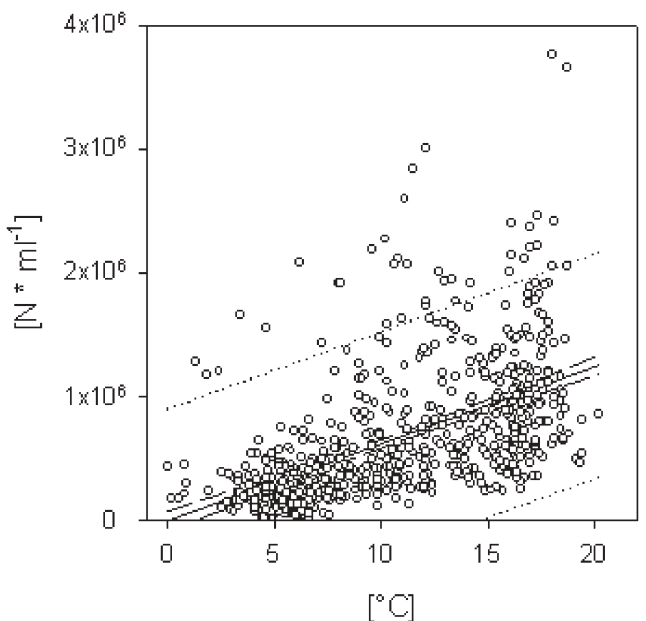

Fig. 2 Correlation between bacterial direct counts (AODC) and water temperature. Dataset 1988 to $2003\left[\mathrm{~N}=741 ; r^{2}=0.286\right.$; AODC $\left.\left(\mathrm{N} \mathrm{ml}^{-1}\right)=-12,670+{ }^{\circ} \mathrm{C} \times 61,000\right]$. Medium dashed line $P<0.5$ confidence interval; dotted line $P<0.5$ prediction interval

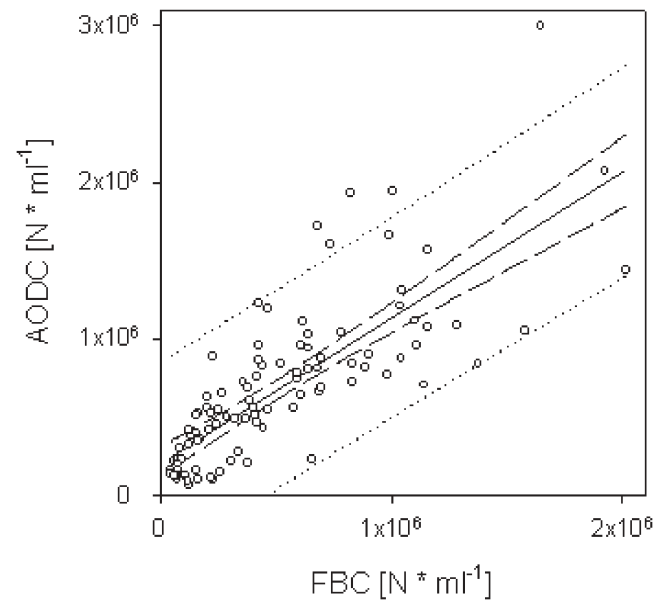

Fig. 3 Correlation between AODC and FBC. Dataset June 1996 to July $1998\left[\mathrm{~N}=103 ; r^{2}=0.609\right.$; AODC $\left(\mathrm{N} \mathrm{ml}^{-1}\right)=211,400+0.925 \times$ FBC $\left.\left(\mathrm{N} \mathrm{ml}^{-1}\right)\right]$. Medium dashed line $P<0.5$ confidence interval; dotted line $P<0.5$ prediction interval

curve may be interpreted as outbursts of fast-dividing bacteria or as the inflow of water masses with high bacterial abundance.

Due to the time-consuming and laborious procedure of bacterial counting, an attempt was made to automate bacterial counts in 1996 by using flowcytometry. In contrast to AODC, the samples were stained with SYTOX. It can be seen that the flowcytometric counts follow AODC nicely (Fig. 1). The linear regression of the two parameters is significant (Fig. 3).

Since Bergh et al. (1989) discovered high numbers of virus particles in the marine environment using electron micrographs, the ecological role of viruses or bacteriophages can no longer be ignored. For the direct counting of virus-like particles (VLP), we decided to apply a method based on direct microscopic counting of the particles after staining them with a DNA dye. GuixaBoixereu et al. (1999) found a significant linear relationship between TEM VLP counts and YOPRO counts. The numbers of VLP in the marine environment commonly exceed $10^{9}$ to $10^{11}$ particles per litre (for review see Wilhelm and Suttle 1999). Winter et al. (2004) also found VLP in the North Sea reaching abundances of about $10^{9}$ particles per litre. Hence, even under the assumption that the application of only one method can over/underestimate the true values of VLP, trends are still visible. In general, on the basis of a 3-year weekly dataset, the seasonal dynamics of viral abundances follow the same abundance patterns as the bacteria (Fig. 1). From low values in winter (November to April) with a minimum of $0.22 \times 10^{6} \mathrm{ml}^{-1}$ in February 2001 the density of VLP increases in late spring (May-October) to a maximum of up to $6.54 \times 10^{6} \mathrm{ml}^{-1}$ in July 2001 . The virus counts were between 2 and 10 times higher than the bacterial counts. In winter, several short-term increases in virus abundance were observed, with virus concentrations of 13 to 16 times the bacterial numbers. This was not correlated with an increase in bacterial abundance. As shown by TEM (Fig. 4), several types of viruses occurred. These viruses displayed a diverse morphology with differences in size and tail structure. Among all the viruses detected in waters around Helgoland, the bacteriophages were recognized by different tail morphologies. Other viruses without tails were assumed to be phytoplankton viruses.

\section{Bacterial diversity and seasonal succession}

Samples for the analyses of the composition of the bacterial community by DGGE on the basis of the 16S-rDNA were taken weekly from August 1996 until the end of 1999. Water samples were fractionated by membrane filtration in two subsets representing "attached bacteria" $(>3 \mu \mathrm{m})$ and "free-living bacteria" $(<3 \mu \mathrm{m}$ to $>0.2 \mu \mathrm{m})$. DNA was successfully extracted from all filter samples. PCR amplification with the primers $\mathrm{P} 2$ and $\mathrm{P} 3$ resulted in DNA fragments of the expected size (233 bp), verified by agarose gel electrophoresis. To resolve the genetic variability of fragments of identical size, the DNA samples were subjected to DGGE. Since only a limited number of samples can be analysed on a single DGGE gel (limited slots), we decided to include standards generated from five randomly chosen bacteria, resulting in five distinct DGGE bands. It should be mentioned that, due to the nonlinear running behaviour of DNA fragments during DGGE, these standards cannot be used in the same way as molecular weight markers applied in native electrophoresis methods. In literature, there is a growing number of publications containing image-analysed DGGE results and derived UPGMA plots. But the transformation DGGE to UPGMA is problematic and should receive much more attention. Bands which are out of range of the standard cannot be interpolated. An interpolation algorithm itself implies that fragments are resolved in a linear manner, because software packages were developed for the anal- 
Fig. 4 Virioplankton in water samples from a station near Helgoland (German Bight). Sampling from April to June 2001 (scale bar represents $80 \mathrm{~nm}$, photographs by $\mathrm{M}$. Schweickert)
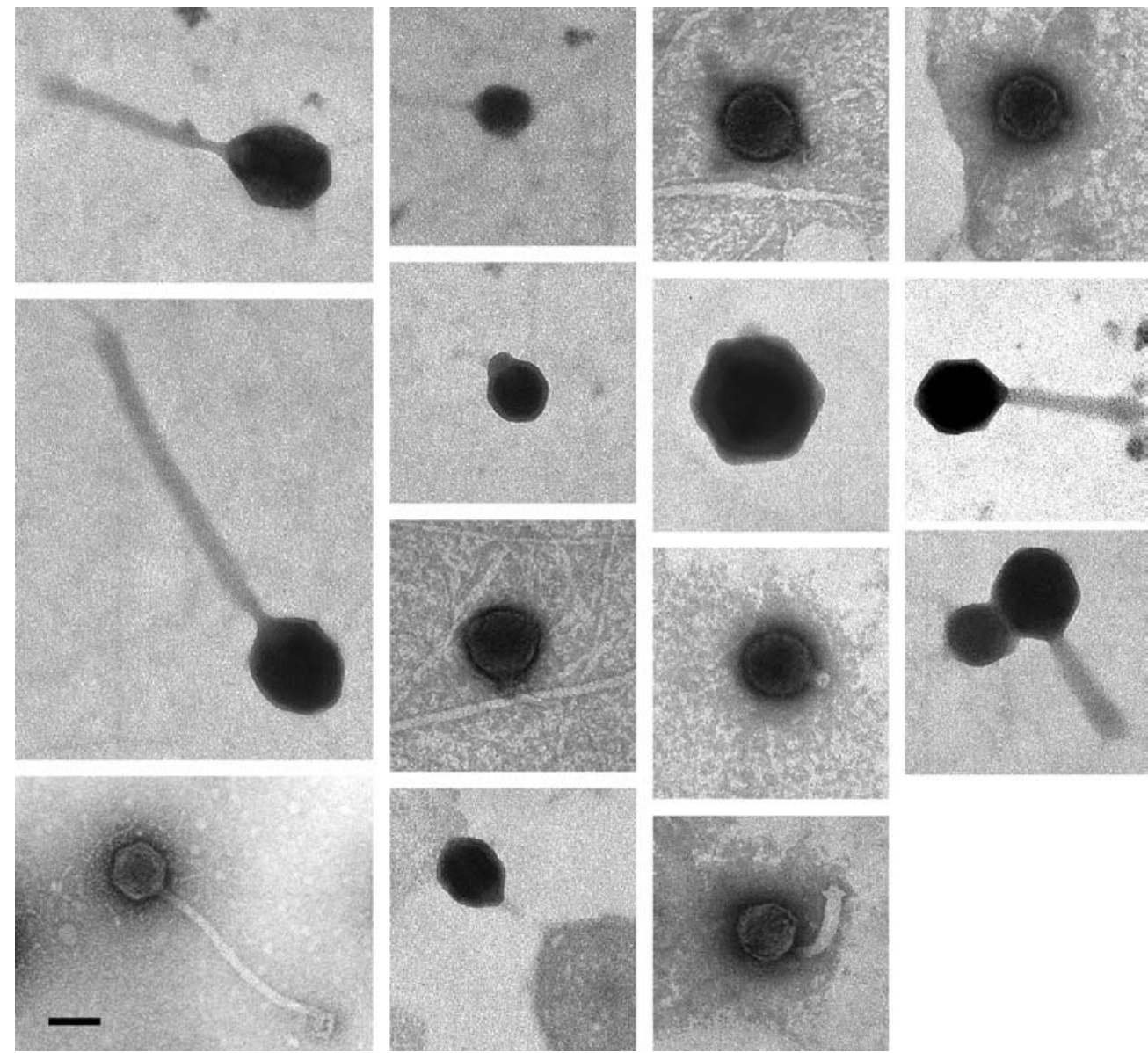

yses of native gels. Furthermore, it should be evaluated whether the analyses should be based on band indices (absence/presence) or, more likely, based on correlation of densitometric values. Hence, we decided to align the individual gels by eye until the pattern of standards, and also the general band pattern, of the corresponding samples overlapped.

Figure 5 shows the combination of 22 individual DGGE gels (11 gels "attached bacteria" fraction; 11 gels "free-living bacteria" fraction). It is obvious that the two fractions generally displayed different band patterns, corresponding to different OTUs (operational taxonomic units). The observation that general temporal or seasonal patterns also occurred is more exciting. During the months October to March, an almost constant band pattern was observed (even with constant band intensities). In March some of the formerly faint bands tended to increase, while others, formerly clearly visible bands, almost vanished. Compared to the previous stable period, the changes in band patterns became dramatic between April and July, followed by a period where the system seems to "calm down" (August and September) resulting finally in a stable "winter situation". Interestingly, the dynamic phase in terms of band pattern changes takes place long before the bacterial counts, or even the water temperature, reach their peaks (Fig. 5). There have been remarkably few long-term (seasonal) studies concerning the microbial diversity in the marine environment using molecular tools as a measure of diversity. Selje and Simon (2003) found in a study on the bacterial community in the Weser Estuary that seasonal differences were less pronounced than those observed in a salinity gradient. In a study on the bacterioplankton diversity of the Catalan coast, Schauer et al. (2000) stated that seasonal succession occurred. Our sampling site in the German Bight displays clear seasonal differences. The plume of the River Elbe, however, could also temporarily influence the bacterioplankton at least during massive flood events (Keller 2003).

\section{Colony-forming units}

For a long time in marine microbiology, CFU was the primary method in experimental work for the quantification and identification of marine bacteria. Beginning in 1962, Koch's plate technique was applied to weekly sampling at the Biologische Anstalt Helgoland for the following 38 years (!). Until April 2000, when we stopped using plate techniques for bacterial quantification purposes, different media were applied and different habitats were sampled (see Table 1). All these efforts were based on the assumption that the bacteria which could be cultivated are somehow important to the ecosystem, while 


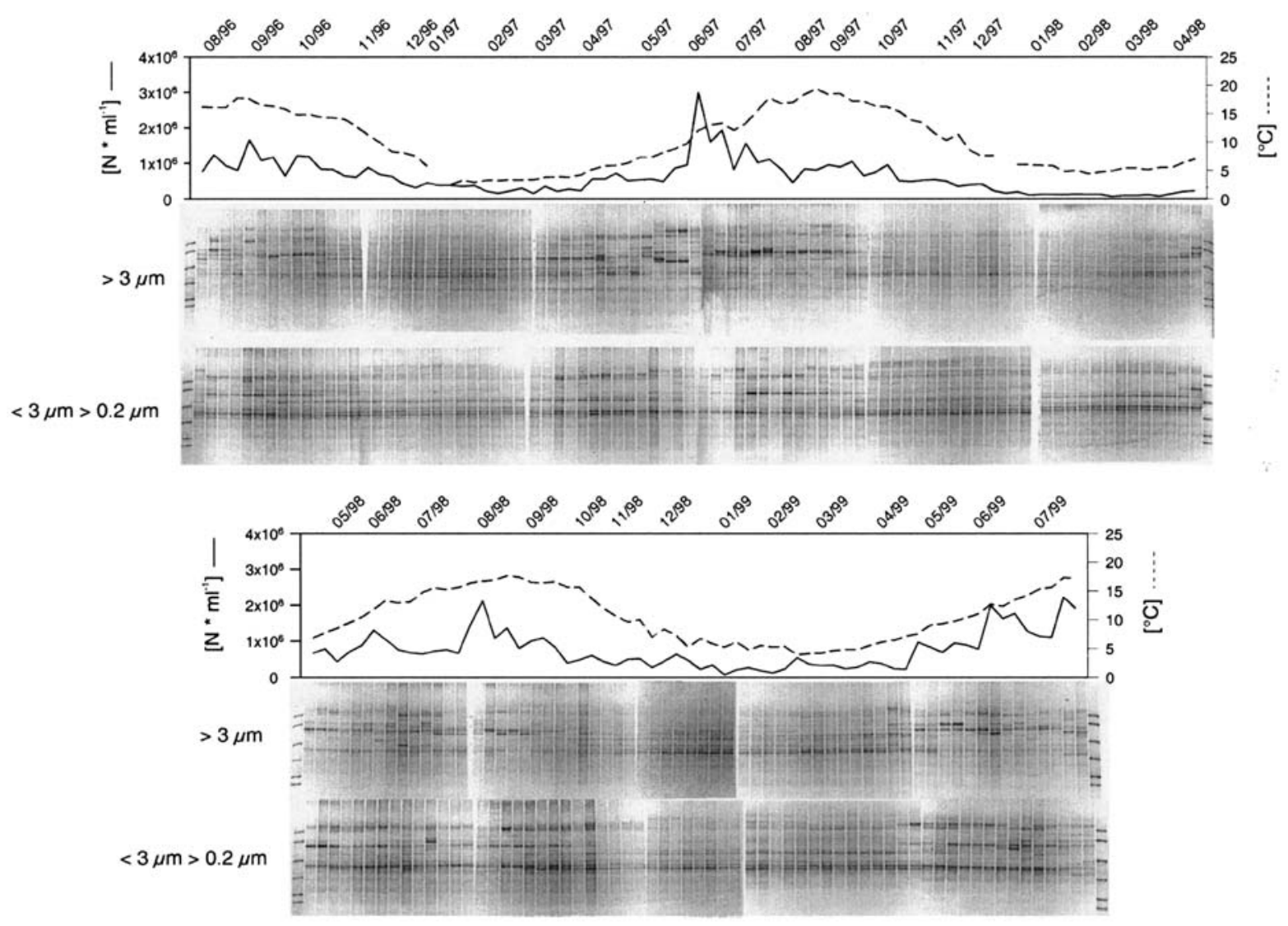

Fig. 5 DGGE profiles of fractionated water samples, corresponding bacterial direct counts (as AODC) and water temperature from August 1996 to July 1999. Sample fraction $1>3 \mu \mathrm{m}$; sample fraction $20.2-3 \mu \mathrm{m}$. DGGE denaturant gradient gel electrophoresis

"the others" are dormant or inactive. Since the introduction of the microscopic direct count method by Hobbie et al. (1977) it has been obvious that there were indeed "others". In 1985, Staley and Konopka (1985) coined the term "great plate count anomaly" for the discrepancy between bacterial counts derived from plating approaches on agar media and those from microscopic examination. By introducing molecular tools to marine microbiology, it can be assumed that the ability to form colonies on agar plates is probably restricted to certain fast-growing $\gamma$-proteobacteria. Besides these, some $\alpha$-proteobacteria (Roseobacter), Bacteroidetes and gram-positive bacteria are commonly co-isolated, but the majority of bacteria which can be cultivated clearly belong to the genera Pseudoalteromonas, Alteromonas and Vibrio. In fact, compared to "the others", these cultivable bacteria only occur in small numbers in marine waters and can hardly be detected by modern molecular tools (Eilers et al. 2000a, 2000b, 2001). On the other hand, it can be hypothesized that due to their ability to conserve high levels of ribosomes during periods of non-growth (Flärdh et al. 1992; Eilers et al. 2000b) these genera have the potential to outgrow other bacterial genera and are able to react preferentially to nutrient re-supply in the environment. For this opportunistic life strategy, Poindexter (1982) coined the term "feast-and-famine existence".
However, the fast-growing $\gamma$-proteobacteria clearly do not dominate the bacterioplankton in nature. Two important regulation factors in the marine environment controlling the bacterial population size that have been considered so far are flagellates and viruses (Smetacek 2002; Wichels et al. 2002). Beardsley et al. (2003), who investigated the suppression of bacteria which can be cultivated, assumed that the fast-growing bacteria, in particular, are strictly controlled by flagellates. From our data, it might indeed be presumed that these fast-dividing bacteria can be a favoured food source for bacterivorous eukaryotes, which subsequently control the bacterial population and, together with bacteriophages, are the cause of upper population thresholds. In Fig. 6, running averages of AODC, FDC and CFUs are displayed from January 1995 to December 1997 (Fig. 6A) and from January 1998 to December 2000 (Fig. 6B). Additionally, Fig. 6A displays the percentage of large rod-shaped bacteria $(>2.5 \mu \mathrm{m})$ as examined by AODC. It is obvious that bacterial and flagellate direct counts correspond to one another. In early spring 1996 we observed unusually high percentages of large rods in the bacterioplankton, followed by a steep increase in flagellate abundance. Following peak flagellate counts, the percentage of large rods increased again, accompanied by an increase in CFUs. Although this event was unique, the CFUs tend to display 
Fig. 6 Running averages of bacterial direct counts (AODC; solid grey line) and corresponding percentage of rods $>2.5 \mu \mathrm{m}$ (dotted line), flagellate counts (dashed line) and colony-forming units (solid black line) from January 1995 to December 1996 (A) and from January 1998 to December 1999 (B)

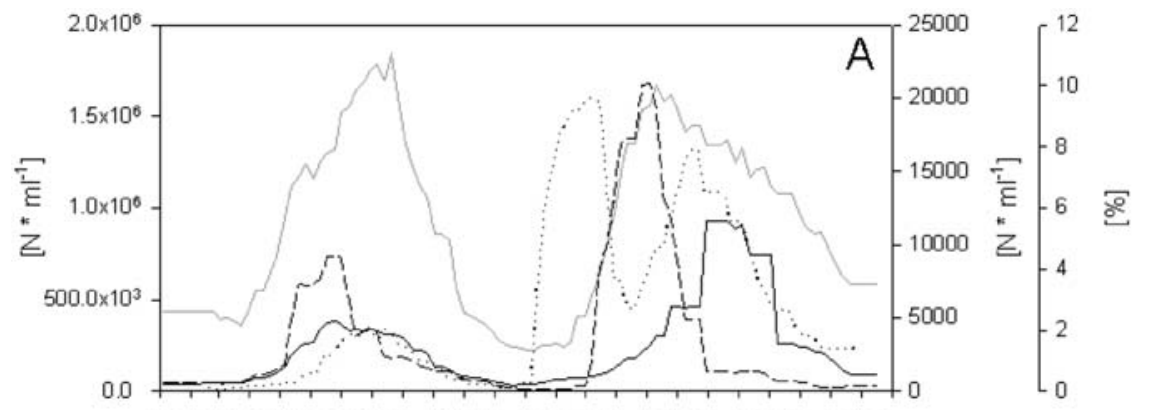

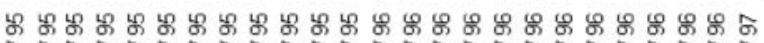

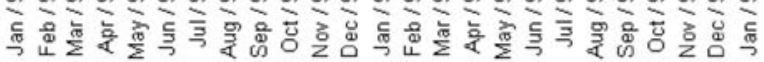

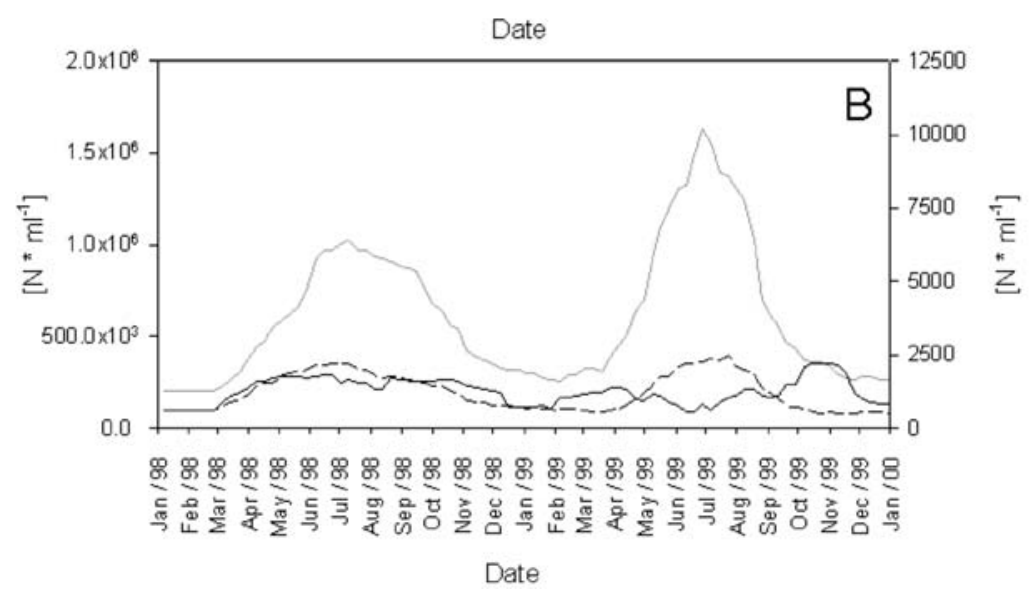

maxima when flagellate counts are low. Currently, we have no idea to which extent the large rods (if not Vibriolike) represent bacteria which can be cultivated or vice versa. Further research is needed to clarify the role of fastgrowing (and cultivable!) bacteria for the nutrition of heterotrophic flagellates, and also for sporadic bursts of bacteriophages in the marine environment.

\section{Measurements of ATP and ectoenzymatic activity}

Samples for the direct in situ evaluation of microbial ATP were taken from December 1989 to May 1993. From September 1994 to November 1996, water samples were examined for ectoenzymatic activity (leucine aminopeptidase). The measurement of ATP was one of the promising methods introduced early in marine microbial ecology by Holm-Hansen and Booth (1966). Karl (1980) continued the work, and published a detailed review in 1980. Attempts were made to estimate and validate ATP/ biomass or ATP/carbon conversion factors but, in comparison to the thymidine uptake method applied later, different factors for different habitats or bacterial populations were acquired, and the method became questionable. Vosjan and Nieuwland (1987) argued that the approximation of bacterial carbon by multiplying the ATP content by 250 is generally acceptable in marine ecosystems with different bacterial populations, more or less in a steady state. We think that the measurement of ATP can indeed give valuable information on the status of bacterial populations in marine ecosystems. As long as bacteria are alive, the synthesis and degradation of ATP is continuous. After death, the production of ATP stops and the compound decomposes rapidly. If total adenylates (adenylate energy charge) are also measured, an exact measure of the metabolic status of the bacteria becomes available. We determined ATP without any of the enzymatic conversions of adenylates necessary for energy charge measurements. Fig. 7 shows the results of a 4 years of ATP measurements of water samples from Helgoland Roads. The data are derived from samples collected from 1-m depth. In the same period, samples were also taken from the neuston and gave similar results or trends (data not shown). In general, the ATP content of filtered water samples reached peak concentrations in June, 1 month before the yearly maximum of the bacterial direct counts (Fig. 7A). Following the argument of Vosjan and Nieuwland (1987), that the ATP/carbon conversion factor of 250 is valid and, furthermore, that bacterial carbon can also be estimated by a biovolume/carbon conversion factor (Bratbak 1985), the results of these estimations of the bacterial biomass can be compared. Hence, for all individual samples we calculated the bacterial carbon using ATP $\left(\mathrm{C}_{\mathrm{ATP}}\right)$ and biovolume $\left(\mathrm{C}_{\mathrm{AODC}}\right)$ conversion factors, and then derived the quotient $\mathrm{C}_{\mathrm{ATP}} / \mathrm{C}_{\mathrm{AODC}}$. Fig. 7B shows monthly combined values of $C_{A T P} / C_{A O D C}$ from winter 1989 to summer 1993. On average, the ATP method overestimates the bacterial carbon (as estimated 

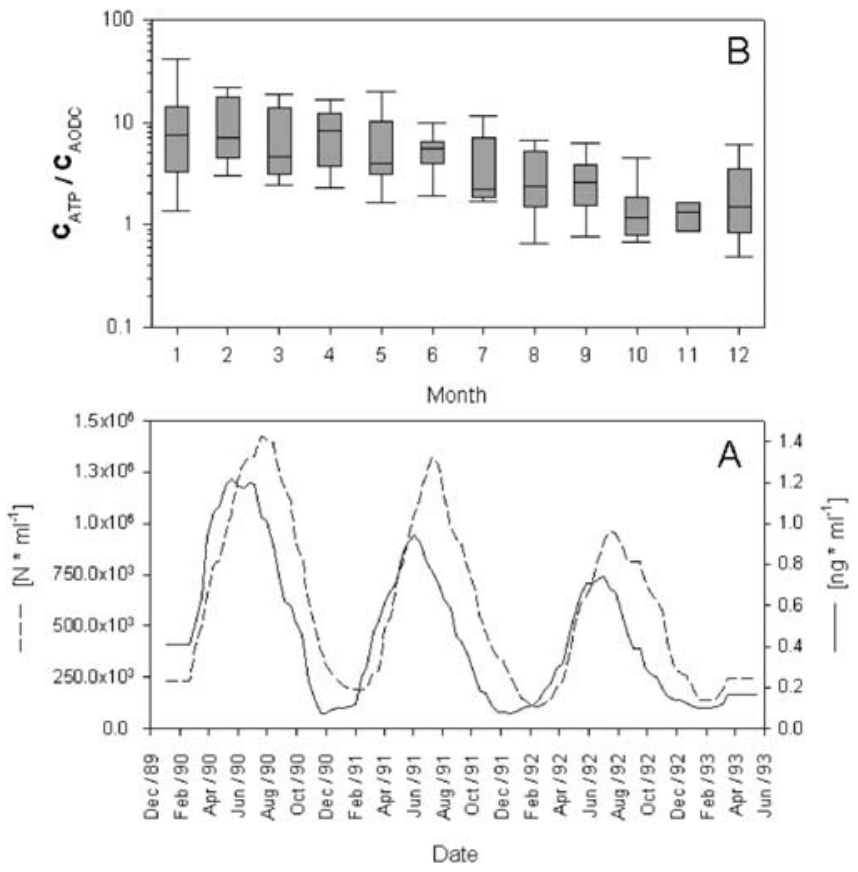

Fig. 7 Running average of ATP concentration (solid black line) and bacterial direct counts (AODC; dashed line) from January 1989 to June 1993 (A). Box and whisker plots of monthly combined quotients of estimated bacterial carbon as calculated using the biovolume- and ATP-conversion factor (B)

by bacterial biovolume) by a factor of 6.3 . Throughout the year, a continuous decline can be observed, with higher calculated quotients in spring and lower quotients in autumn. Three explanations are possible:

1. organisms other than bacteria are co-extracted in spring;

2. "autumn" bacteria are less well extracted, or

3. "spring" bacteria actually contain more ATP.

Although the general mathematical conversion of ATP values to bacterial carbon cannot be recommended, it is obvious that either bacterial metabolic or population changes (or both) take place during early spring. This underpins the findings of the PCR-DGGE profiles, and also those of the ectoenzymatic activity measurements (see below).

Since Hoppe introduced the quantification of hydrolytic capabilities of marine bacteria into marine microbial ecology, a growing number of artificial substrates for different enzymes have been applied and different habitats examined (Hoppe 1993; Riemann et al. 2000; Zaccone et al. 2002). We started to measure leucine aminopeptidase (LAPase) activity in 1994 using the substrate MCA-leucin. Additionally to the incubation at in situ temperatures, we decided to apply a temperature gradient from $0^{\circ} \mathrm{C}$ to $20^{\circ} \mathrm{C}$ covering minimal and maximal water temperatures measured in the field during a year by incubating subsamples in a "thermatron" (Christian and Karl 1995). In Fig. 8, the results of the LAPase mea-
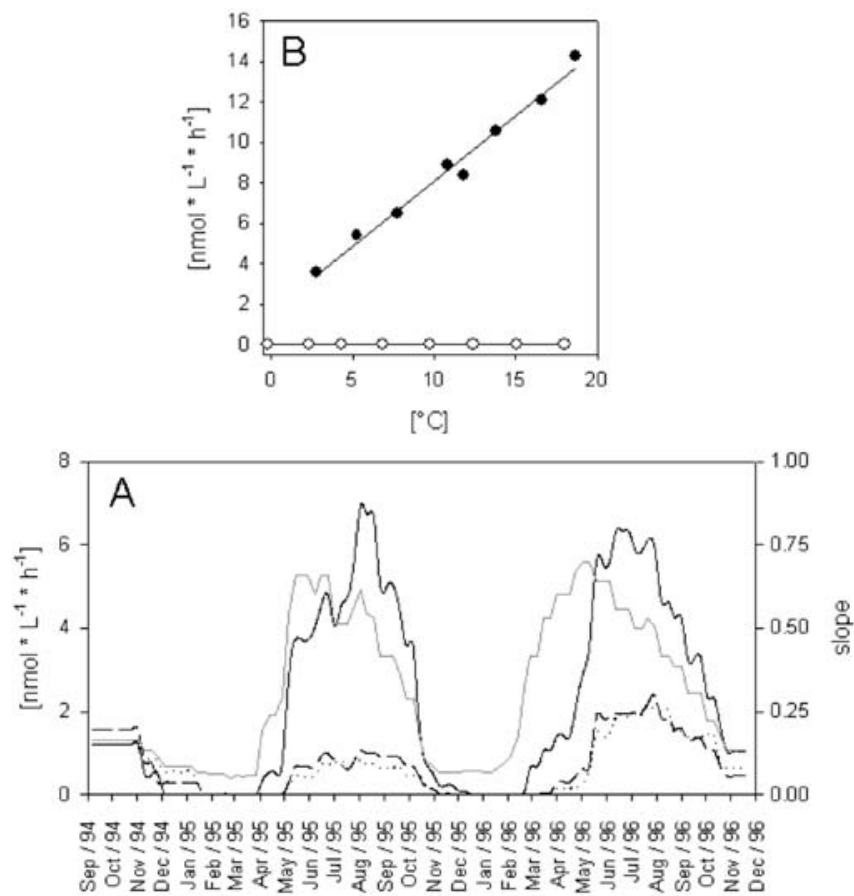

Date

Fig. 8 Running averages of leucine aminopeptidase activity in different sample fractions from September 1994 to December 1996 (A). Sample fractions: not filtrated (solid black line), $<3 \mu \mathrm{m}(\mathrm{da}$ shed line), $<0.2 \mu \mathrm{m}$ (dotted line). Dependence of incubation temperature: calculated regression slopes of individual incubation experiments are shown (A, solid grey line $)$ and exemplary, individual thermatron experiments from January 1995 (B,open circles) and June 1996 (B, filled circles)

surements experiments are shown. In detail, Fig. 8A shows hydrolysis rates measured weekly from September 1994 to December 1996. It is obvious that during the winter months (December to February) no LAPase activity was measurable. Since the samples were incubated for 2 to $3 \mathrm{~h}$, regardless of the water temperature, it can not be excluded that longer incubation is necessary in winter. From March/April the LAPase activity increased, till a peak was reached in mid-summer (July/August) 1995 and 1996. During March and April of 1995 and 1996 the first measurable response of LAPase activity to elevated incubation temperatures in "thermatron" experiments was observed. Although in the winter months no correlation between LAPase activity and incubation temperature was measurable, in summer this response was linear for most of the samples, without displaying an optimum in the range of $0-20^{\circ} \mathrm{C}$. In Fig. 8B, incubation temperature-dependent measurements of LAPase activity are displayed exemplarily for samples from January 1995 and June 1996. Fig. 8A displays the slopes of all regressions. Most striking is that even in early spring a temperature dependent response of LAPase is observable, whereas no increased hydrolysis rates can be measured at in situ temperatures. Since both qualitative and quantitative changes take place in the composition of the bacterial 
population in spring, according to the results of the PCRDGGE profiling, it can be assumed that bacteria other than those of the winter population are responsible for the elevated LAPase activity. On the other hand, it can also be argued that the winter population, which is also present throughout the year to some extent, does not express any LAPase below a certain water temperature or stimulus. Further research is needed to couple this information in terms of functional diversity and to identify the sources of LAPase activity.

The filtration of water samples generally leads to reduced activity in filtered fractions. On average, 29\% (median 21\%) of the initial activity could be measured for the $<3 \mu \mathrm{m}$ fraction, and $23 \%$ (median 17\%) for the $<0.2 \mu \mathrm{m}$ fraction. Hence, at least two thirds of the proteolytic activity was particle-associated and was removed by filtration on $3-\mu \mathrm{m}$ filters. Furthermore, since there was no measurable difference between the $<3 \mu \mathrm{m}$ and $<0.2 \mu \mathrm{m}$ fractions, one third of the total activity cannot be directly linked to bacterial cells and must be "free-enzyme". This underpins the unique role of marine aggregates as "hotspots" in the water column, and also sources of enzymatic activity as already stated by different authors (Smith et al. 1992; Middelboe et al. 1995). It may even be possible that, during the colonisation of aggregates by bacteria, the expression of ectoenzymes can be "quorum-sensing" dependent (Gram et al. 2002), but this needs to be examined in future studies.

\section{"Historical" parameters: oil-degrading bacteria, "marine" yeasts, biological oxygen demand, surface tension and TOC measurements}

With an increasing concern about marine pollution in the 1970s, parameters were needed to describe anthropogenic impact on marine ecosystems. One parameter, introduced by Gunkel (1973), was the quantification of oil-degrading bacteria by the most probable number technique using crude oil as a carbon source. In Fig. 9A, the numbers of oil-degrading bacteria (ODB) are displayed as box and whisker plots of combined yearly data from 1980 to 1993. Compared to CFU values, the ODB reach much lower counts with a median of $15 \mathrm{~N} \mathrm{ml}^{-1}$ for the whole dataset. Peak counts reached up to $9,300 \mathrm{~N} \mathrm{ml}^{-1}$. During the examination period, the ODB counts increased from 1980 to 1985 , decreased in the following 2 years and reached a maximum again in 1988. From 1988 to 1993 , a continuous decrease was observed in ODB, possibly due to political efforts leading to official laws regulating the flushing of ballast water. Concerning monthly data (Fig. 9B), elevated ODB values were detected in early summer and during winter, in contrast to spring and autumn where ODB counts are low. ODB counts from the neuston exceed those from 1-m depth by a factor of 20 (median) or even a factor of 1,000, concerning the arithmetic mean (Fig. 9B). Plusquellec et al. (1989) estimated the bacterial enrichment in the neuston to range from 24- to 720-fold compared to subsurface water. In contrast to total bacterial
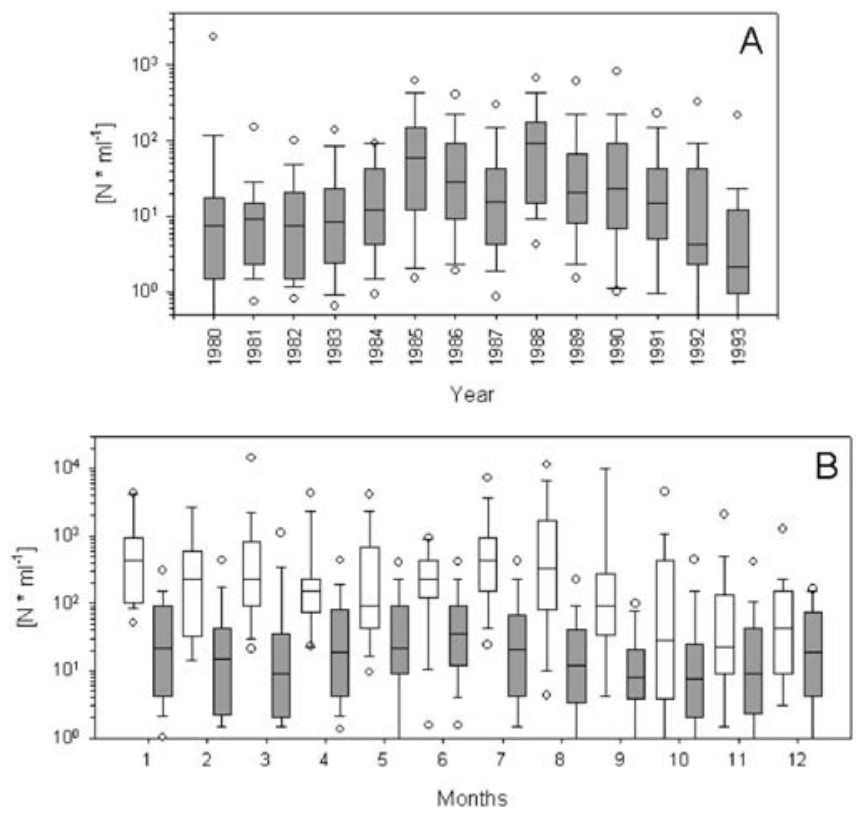

Fig. 9A, B Box and whisker plots of MPN (most probable number) values indicating oil-degrading bacteria from 1980 to 1993 . Displayed are yearly (A) and monthly (B) combined data of samples from the neuston (open boxes) and from 1-m depth (grey boxes)

counts, which are on average lower in the surface layer compared to subsurface (see above), oil-degrading bacteria are enriched in the microlayer, presumably due to hydrophobic cell-surface structures (Rosenberg and Rosenberg 1985). Hence, a shift in community structure should be expected by comparing the two habitats. It would be interesting to apply molecular tools to underpin this finding. It can be assumed that dramatic oil impacts in the marine environment will occur in the future, following accidents such the "Pallas" disaster in 1998 in the German Bight or, more recently (2002), the "Prestige" off the Galician coast. As a consequence, besides expected shortand long-term affects on the complete ecosystem, the structure of bacterial populations will change, and bacteria capable of degrading hydrocarbons will increase (Macnaughton et al. 1999; Reckermann et al. 1999; Röling et al. 2002; Maruyama et al. 2003). Hence, further research is needed by combining traditional (Minas and Gunkel 1995) and modern molecular (Syutsubo et al. 2001; Sei et al. 2003) approaches.

The most basic approach for the detection of oxygenic microbial metabolism is to quantify respiration. Microbial respiration can also be a measure of degradable organic matter in the ecosystem. The determination of the biological oxygen demand was introduced in 1965 and continued for 28 years. Fig. 10 shows the biological oxygen demand as box and whisker plots of combined yearly data. Again general trends are visible. From the beginning of the measurements, a yearly increase from below $2 \mathrm{mg} \mathrm{l}^{-1}$ to almost $4 \mathrm{mg} \mathrm{l}^{-1}$ in $1977 / 78$ can be observed. From the end of the 1970s the values decreased, reaching a value comparable to the 1960s. However, a measure like BOD is questionable in describing ecologi- 


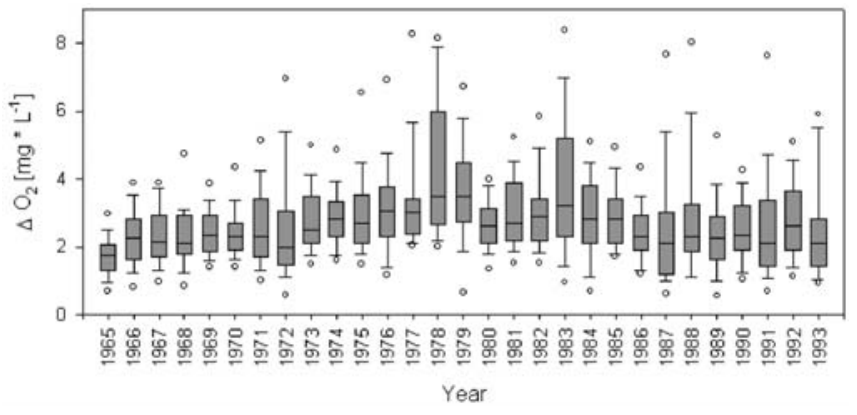

Fig. 10 Box and whisker plots of biological oxygen demand (BOD) from 1965 to 1993
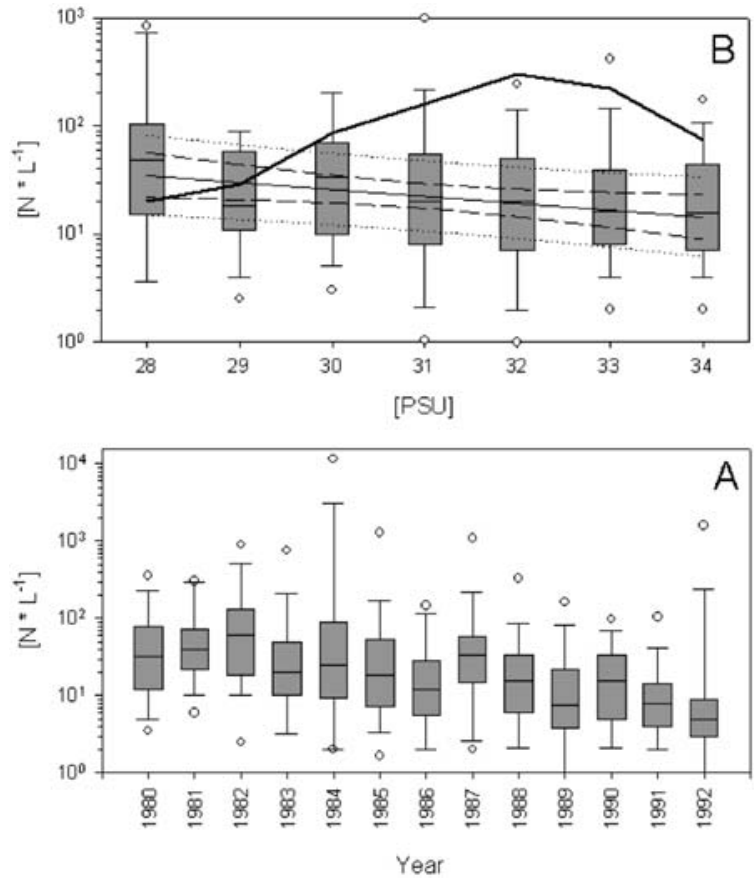

Fig. 11A, B Box and whisker plots of yeast counts from 1980 to 1992. Displayed are yearly (A) and salinity (B) combined data. Linear regression of yeast counts (median) versus salinity and the number of corresponding data (solid bold line). Medium dashed line $P<0.5$ confidence interval; dotted line $P<0.5$ prediction interval

cal conditions, but the trends detected do reflect general historical changes in marine pollution loads by nitrate, phosphate or organic nutrients.

Another "historical" parameter at Helgoland Roads is the quantification of marine yeasts. In Fig. 11, the counts of marine yeasts are displayed as box and whisker plots of yearly combined data from 1980 to 1992 (Fig. 11A) and as combined data for different salinities (Fig. 11B). It is obvious that a general decrease was observed until 1992 from the start of the yeast counts. Whether this trend may be linked to a reduction in marine pollution can be hypothesized, but remains speculative. During an average year, the yeast counts decrease from March to May, and reach higher values in autumn (not shown). The halotolerance of these organisms (Urano et al. 2001) is often discussed, leading to the question of to what extent marine yeasts are autochthonous. From our data, a salinity optimum cannot be deduced. Not surprisingly, with increasing salinity the yeast counts decrease (yeast counts $=151-4.1 \times$ salinity, $r=0.76$ ). These results may be evidence to suggest a former fresh or brackish water origin of marine fungi. Due to their outstanding physiological capabilities, marine yeasts receive increasing interest in marine natural products research (Bugni and Ireland 2003) and therefore may be included again in the repertoire of the microbiological parameters of the "Kabeltonne".

\section{Conclusions}

After the stimulating publication of Pomeroy (1974) on oceanic food webs, many methods were developed trying to elucidate this new idea. However, it seems that marine microbiologists are still at the stage of continuous method evolution to find tools for the description of the role of bacteria in the marine food web. In recent years, several promising molecular biology approaches have been adapted from medical science and have revolutionized marine microbial ecology. The most popular tools are based on 16S-rDNA signature sequences and are either probe- (FISH techniques) or primer-based (PCR techniques). For the first time, these tools permitted (and still permit) new insights, in terms of diversity and identity, into the in situ characteristics of marine bacterial populations. On the other hand, modern molecular methods can also be strongly biased. Hence multiphasic approaches, covering different molecular methods, are favourable.

One of these recently developed and promising methods combines FISH techniques with catalyzed reporter deposition (Pernthaler et al. 2002a) in order to enhance the hybridization signal (CARD-FISH; catalysed reporter deposition). By using an incubation technique with bromodeoxyuridine (BrdU) as a thymidine analogue, it is even possible to discriminate between DNA-synthesizing bacterial cells and dormant cells (Pernthaler et al. 2002b). The development of automated enumeration of FISH counts by the combination of epifluorescence microscopy and image analysis (Pernthaler et al. 2003), and the introduction of microfluidics-based flowcytometers to marine microbial ecology (Gerdts and Lüdke, in preparation) are also promising (and time-saving). A combination of FISH and micro-autoradiography could make it feasible to perform function analysis of specific bacterial communities or habitats in the environment (Lee at al. 1999).

Another approach is based on PCR techniques. DGGE, which has already been applied to our long-term studies of bacterial populations in the Helgoland Roads, was presented here. For future analysis of marine bacterial populations, we suggest a step-by-step approach beginning with PCR fingerprinting techniques based on native electrophoresis, such as ribosomal intergenic spacer analysis (RISA; Ranjard et al. 2001) or the analysis of 
repetitive extragenic palindromic sequences (repPCR; de Bruijn et al. 1996; Baker et al. 2003), which can be analyzed by automated image analysis software. With a PCR-DGGE approach, resolving larger 16S-rDNA fragments (Seibold et al. 2001; Schäfer et al. 2002; Wichels et al. 2004), it should be possible to identify OTUs by DGGE band sequencing and thus obtain a closer look at the bacterial community structure.

Recently it has been demonstrated that bacteriophages may be responsible for $20-50 \%$ of bacterial mortality in marine ecosystems, and are important in shaping microbial communities (Fuhrmann 1999; Wommack and Colwell 2000). To study the diversity of marine phages or viruses, pulsed field gel electrophoresis (PFGE) can be used to generate fingerprints of these viral communities (Wommack et al. 1999). At the Biologische Anstalt Helgoland, a culture collection of marine phage-host systems, containing more than 200 bacterial host strains and their specific bacteriophages has been built up during the last 15 years. Some host bacteria belong to the $\gamma$ subdivision of proteobacteria, and a few to the bacteroidetes phylum, but most remain unidentified. On the basis of the information provided by the complete sequence of the Roseophage genome SOI1 (Rohwer et al. 2000) the existence of similarities of functional genes for DNA polymerase, primase and endodesoxyribonuclease I was discovered. It would be interesting to screen the Helgoland culture collection of marine phage-host systems for these functional genes as a starting point for future specific primer and probe design. This approach has already been successfully used for phytoplankton viruses (e.g. Micromonas pusilla), pathogen viruses and coliphages (Gantzer et al. 1998; Griffin et al. 1999; Ikeda and Gray 1999). Furthermore, the data can provide exciting information on the potential transfer of functional genes between phages and bacteria. The expected insights into marine virioplankton diversity will grant the necessary knowledge to elucidate the influence of phages on the bacterial community structure.

The scientific work which has been performed at the Biologische Anstalt Helgoland reflects the development in general marine microbiology. Beginning in 1962, W. Gunkel initialized the microbial examinations at Helgoland Roads and the first water samples where analysed bacteriologically from the famous location "Kabeltonne". Over the years, and of course according to the development of new methods and approaches (and fashions) by the scientific community, some methods were affiliated to the microbiological repertoire and data were recorded for a period of time. One might argue that the deeper reason for recording these data was, for example, to parameterize marine pollution or (as a view from today) global warming. Regarding oil-degrading bacteria or biological oxygen demand, the motivation of data collection is clear, but as pure basic science, some data were also recorded because it was possible to record these data and to evaluate methods suitable for marine microbial ecology. Some years ago, however, the molecular age changed our microbiological repertoire, and parameters like CFU were finally rejected. The aim of this review was to present an overview on the multitude of microbiological approaches performed at the Biologische Anstalt Helgoland during 40 years of studying bacteria in the German Bight.

As can be seen from the results presented in this study, each method used in the long-term studies in Helgoland Roads had its advantages and disadvantages, and only a well-tuned combination of new and already established methods will broaden our understanding of the role of bacteria in the marine food web and will help the scientific community to improve the knowledge of microbial oceanography. Based mainly on results of the PCRDGGE profiling of bacterial diversity and seasonal succession over a longer period, we always observed two phases per year when dynamic shifts in the population structure occurred.

The oceanic food web, and especially the interactions between bacteria, phytoplankton and zooplankton, are still one of the most challenging systems. From the microbiological point of view, we are still at the beginning of understanding the marine microbial world, and hopefully we are becoming more aware of the tools and methods urgently needed. The integration of studies on marine bacteria into oceanographic long-term studies using new methods to identify organisms, structure and function of specific organisms, communities and habitats will be one of our greatest challenges in the future.

Acknowledgements We are deeply indebted to Prof. W. Gunkel, who initiated the microbiological survey at the sampling station "Kabeltonne" near Helgoland in 1962. This long-term study was only possible due to his devoted work and a great number of laboratory technicians (E. Wollny, T. Hennemann, A. Sawall, E.H.J. Trekel, U. Henseleit) and crew members of the research boats "Ellenbogen" and Aade from the Biologische Anstalt Helgoland.

\section{References}

Anderson DG, McKay LL (1983) Simple and rapid method for isolating large plasmid DNA from lactic streptococci. Appl Environ Microbiol 46:549-552

Baker CJO, Fulthorpe RR, Gilbride KA (2003) An assessment of variability of pulp mill wastewater treatment system bacterial communities using molecular methods. Water Qual Res J Can 38:227-242

Beardsley C, Pernthaler J, Wosniok W, Amann R (2003) Are readily culturable bacteria in costal North Sea waters suppressed by selective grazing mortality? Appl Envir Microbiol 69:2624-2630

Bergh O, Borsheim KY, Bratbak G, Heldal M (1989) High abundances of viruses found in aquatic environments. Appl Envir Microbiol 340:467-468

Bratbak G (1985) Bacterial biovolume and biomass estimations. Appl Environ Microbiol 49:1488-1493

Bruijn FJ de, Rademaker J, Schneider M, Rossbach U, Louws FJ (1996) Rep-PCR genomic fingerprinting of plant-associated bacteria and computer-assisted phylogenetic analyses. In: Stacey G, Mullin B, Gresshoff P (eds) Biology of plant-microbe interaction; proceedings of the 8th international congress of molecular plant-microbe interactions. APS Press, pp 497-502

Bugni TS, Ireland CM (2003) Marine-derived fungi: a chemically and biologically diverse group of microorganisms. Nat Prod Rep 21:143-163 
Christian JR, Karl DM (1995) Bacterial ectoenzymes in marine waters: activity ratios and temperature responses in three oceanographic provinces. Limnol Oceanogr 40:1042-1049

Deutsche Einheitsverfahren zur Wasser-Abwasser und Schlammuntersuchungen (1983) Fachgruppe Wasserchemie in der Gesellschaft Deutscher Chemiker (ed) Verlag Chemie, Weinheim/ Bergstrasse (BRD). Einheitsverfahren für Wasser, Abwasser und Schlammuntersuchungen (1988)

Eilers H, Pernthaler J, Glöckner FO, Amann R (2000a) Culturability and in situ abundance of pelagic bacteria from the North Sea. Appl Environ Microbiol 66:3044-3051

Eilers H, Pernthaler J, Amann R (2000b) Succession of pelagic marine bacteria during enrichment: a close look at cultivationinduced shifts. Appl Environ Microbiol 66:4634-4640

Eilers H, Pernthaler J, Peplies J, Glöckner FO, Gerdts G, Amann R (2001) Isolation of novel pelagic bacteria from the German Bight and their seasonal contributions to surface picoplankton. Appl Environ Microbiol 67:5134-5142

Fell JW, Ahearn DG, Meyers SP, Roth FJ Jr (1960) Isolation of yeasts from Biscayne Bay, Florida and adjacent benthic areas. Limnol Oceanogr 5:366-371

Flärdh K, Cohen PS, Kjelleberg S (1992) Ribosomes exist in large excess over the apparent demand for protein synthesis during carbon starvation in marine Vibrio sp. strain CCUG15956. J Bacteriol 174:6780-6788

Fuhrman J (1999) Marine viruses and their biogeochemical and ecological effects. Nature 399:541-48

Gantzer C, Maul A, Audic JM, Schwartzbrod L (1998) Detection of infectious enteroviruses, enterovirus genomes, somatic coliphages, and Bacteroides fragilis phages in treated wastewater. Appl Environ Microbiol 64:4307-4312

Gram L, Grossart HP, Schlingloff A, Kiørboe (2002) Possible quorum sensing in marine snow bacteria: Production of acylated homoserine lactones by Roseobacter srains isolated from marine snow. Appl Environ Microbiol 68:4111-4116

Griffin DW, Gibson CJ 3rd, Lipp EK, Riley K, Paul JH 3rd, Rose JB (1999) Detection of viral pathogens by reverse transcriptase PCR and of microbial indicators by standard methods in the canals of the Florida Keys. Appl Environ Microbiol 65:41184125

Guixa-Boixereu N, Lysnes K, Pedros-Alio C (1999) Viral lysis and bacterivory during a phytoplankton bloom in a coastal water microcosm. Appl Environ Microbiol 65:1949-1958

Gunkel W (1973) Distribution of oil-oxidizing bacteria in the North Sea. In: Meyers SP (ed) The microbial degradation of oil pollutants. Lousiana State University, Baton Rouge, USA, pp 127140

Hennes KP, Suttle CA (1995) Direct count of viruses in natural waters and laboratory cultures by epifluorescence microscopy. Limnol Oceanogr 40:1050-1055

Hobbie JE, Daley R-J, Jaspers S (1977) Use of nucleopore filters for counting bacteria by fluorescence microscopy. Appl Environ Microbiol 33 1225-1228

Holben WE, Jansson JK, Chelm BK, Tiedje JM (1988) DNA probe method for the detection of specific microorganisms in the soil bacterial community. Appl Environ Microbiol 54:703-711

Holm-Hansen O, Booth CR (1966) The measurement of adenosine triphosphate in the ocean and its ecological significance. Limnol Oceanogr 11:510-519

Hoppe HG (1993) Use of fluorogenic model substrates for extracellular enzyme activity measurement of bacteria. In: Kemp PF (ed) Handbook of methods in aquatic microbial ecology. Lewis, pp 423-430

Ikeda TM, Gray MW (1999) Protein, nucleotide identification and characterization of T3/T7 bacteriophage-like RNA-polymerase sequences in wheat. Plant Mol Biol 40:567-78

Karl DM (1980) Cellular nucleotide measurements and applications in microbial ecology. Microbiol Rev 44:739-796

Keller L (2003) Herbstsukzession und Aktivität der pelagischen Bakteriengemeinschft in der Deutschen Bucht. Diploma thesis, Bremen University
Lee N, Nielsen PH, Andreasen KH, Juretschko S, Nielsen JL, Schleifer K-H, Wagner M (1999) Combination of fluorescent in situ hybridization and microautoradiography - a new tool for structure-function analyses in microbial ecology Appl Environ Microbiol 65:1289-1297

Macnaughton SJ, Stephen JR, Venosa AD, Davis GA, Chang Y-J, White DC (1999) Microbial population changes during bioremediation of an experimental oil spill. Appl Environ Microbiol 65:3566-3574

Maruyama A, Ishiwata H, Kitamura K, Sunamura M, Fujita T, Matsuo M, Higashihara T (2003) dynamics of microbial populations and strong selection for Cycloclsticus pugetii following Nakhoda oil spill. Microb Ecol 46:442-453

Middelboe M, Søndergaard M, Letarte Y, Borch NH (1995) Attached and free-living bacteria: production and polymer hydrolysis during a diatom bloom. Microb Ecol 29:231-248

Minas W, Gunkel W (1995) Oil pollution in the North Sea-a microbiological point of view. Helgol Meeresunters 49:143158

Muyzer G, Waal de EC, Uitterlinden AG (1993) Profiling of complex microbial populations by denaturing gradient gel electrophoresis analysis of polymerase chain reaction-amplified genes coding for 16S rRNA. Appl Environ Microbiol 59:695700

Oppenheimer CH, ZoBell CE (1952) The growth an viability of sixty three species of marine bacterias influenced by hydrostatic pressure. J Mar Res 11:10-18

Pernthaler A, Pernthaler J, Amann R (2002a) Fluorescence in situ hybridization and catalyzed reporter deposition for the identification of marine bacteria. Appl Environ Microbiol 68:30943101

Pernthaler A, Pernthaler J, Schattenhofer M, Amann R (2002b) Identification of DNA-synthesizing bacterial cells in coastal North Sea plankton. Appl Environ Microbiol 68:5728-5736

Pernthaler J, Pernthaler A, Amann R (2003) Automated enumeration of groups of marine picoplankton after fluorescence in situ hybridization. Appl Environ Microbiol 69:2631-2637

Plusquellec A, Beucher M, Le Lay C, Le Gal Y, Cleret JJ (1989) Quantitative and qualitative bacteriology of the marine water surface microlayer in a sewage-pollute area. Mar Environ Res 31:227-239

Poindexter JS (1982) Oligotrophy: feast and famine existence. Adv Microb Ecol 5:63-89

Pomeroy LJ (1974) The ocean's food web, a changing paradigm. Bioscience 24:499-504

Ranjard L, Poly F, Lata J-C, Mougel C, Thioulouse J, Nazaret S (2001) Characterization of bacterial and fungal soil communities by automated ribosomal intergenic spacer analysis fingerprints: biological and methodological variability. Appl Environ Microbiol 67:4479-4487

Reckermann M, Poremba K, Colijn F (1999) Untersuchungen zur Auswirkung der Pallas-Havarie auf die Bakterio- und Phytoplanktongemeinschaft des Wattenmeeres. Berichte, Forsch.und Technologiezentrum Westküste des Universität Kiel Nr. 20

Riemann L, Steward GF, Azam F (2000) Dynamics of bacterial community composition and activity during a mesocosm diatom bloom. Appl Environ Microbiol 66:578-587

Rohwer F, Segall A, Steward G, Seguritan V, Breitbart M, Wolven F, Azam F (2000) The complete genomic sequence of the marine phage Roseophage SIO1 shares homology with nonmarine phages. Limnol Oceanogr 45:408-418

Röling WFM, Milner MG, Jones DM, Lee K, Daniel F, Swannel RJP, Head IM (2002) Robust hydrocarbon degradation and dynamics of bacterial communities during nutrient-enhanced oil spill bioremediation. Appl Environ Microbiol 68:5537-5548

Rosenberg M, Rosenberg E (1985) Bacterial adherence to the hydrocarbon-water interface. Oil Petrochem Poll 2:155-162

Schäfer H, Abbas B, Witte H, Muyzer G (2002) Genetic diversity of 'satellite' bacteria present in cultures of marine diatoms. FEMS Microbiol Ecol 42:25-35

Schauer M, Massana R, Pedros-Alio C (2000) Spatial differences in bacterioplankton composition along the Catalan coast (NW 
Mediterranean) assessed by molecular fingerprinting. FEMS Microb Ecol 33:51-59

Sei K, Sugimoto Y, Mori K, Maki H, Kohno T (2003) Monitoring of alkane-degrading bacteria in a sea-water microcosm during crude oil degradation by polymerase chain reaction on alkanecatabolic genes. Environ Microbiol 5:517-522

Seibold A, Wichels A, Schuett C (2001) Diversity of endocytic bacteria in the dinoflagellate Noctiluca scintillans. Aquat Microb Ecol 25:229-235

Selje N, Simon M (2003) Composition an dynamics of bacterial associated and free-living bacterial communities in the Weser Estuary, Germany. Aquat Microb Ecol 30:221-237

Smetacek V (2002) Microbial food webs: the ocean's veil. Nature 419:565

Smith DC, Simon M, Alldredge AL, Azam F (1992) Intense hydrolytic enzyme activity on marine aggregates and implications for rapid particle dissolution. Nature 359:139-142

Somville M, Billen G (1983) A method for determining exoproteolytic activity in natural waters. Limnol Oceanogr 28:190193

Staley JT, Konopka A (1985) Measurements of in situ activities of nonphotosynthetic microorganisms in aquatic and terrestrial habitats. Annu Rev Microbiol 39:321-346

Syutsubo K, Kishira H, Shigeaki H (2001) Development of specific oligonucleotide probes for the identification and in situ detection of hydrocarbon-degrading Alcanivorax strains. Environ Microbiol 3:371-379

Urano N, Yamazaki M, Ueno R (2001) Distribution of halotolerant and/or fermentative yeasts in aquatic environments. J Tokyo Univ Fisheries 87:23-29

Vosjan JH, Nieuwland G (1987). Microbial biomass and respiratory activity in the surface waters of the east Banda Sea and the northwest Arafura Sea (Indonesia) at the time of the southeast monsoon. Limnol Oceanogr 32:767-775

Wichels A, Gerdts G, Schuett C (2002) Pseudoalteromonas spp. phages, a significant group of marine bacteriophages in the North Sea. Aquat Microb Ecol 27:233-239

Wichels A, Schütt C, Hummert C, Elbrächter M, Luckas B, Gerdts $\mathrm{G}$ (2004) Bacterial diversity in toxic Alexandrium tamarense blooms off the Orkney Isles and the Firth of Forth. Helgol Mar Res (in press)

Wilhelm SW, Suttle CA (1999) Viruses and nutrient cycles in the sea. Bioscience 49:781-

Winter C, Herndl GJ, Weinbauer MG (2004) Diel cycles in viral infection of bacterioplankton in the North Sea. Aquat Microb Ecol 35:207-216

Wommack KE, Ravel J, Hill RT, Chun J, Colwell RR (1999) Population dynamics of Chesapeake Bay virioplankton: totalcommunity analysis by pulsed-field gel electrophoresis. Appl Environ Microbiol 65:231-240

Wommack KE, Colwell RR (2000) Viruses in aquatic ecosystems. Microb Mol Biol Rev 64:69-114

Xenopoulus MA, Bird DF (1997) Virus à la sauce Yo-Pro: microwave-enhanced staining for counting viruses by epifluorescence microscopy. Limnol Oceanogr 42:1618-1650

Zaccone R, Caruso G, Cali C (2002) Heterotrophic bacteria in the northern Adriatic Sea: seasonal changes and ectoenzyme profile. Mar Environ Res 54:1-19

Zimmermann R, Meyer-Reil LA (1974) A new method for fluorescence staining of bacteria populations on membrane filters. Kieler Meeresforsch 30:24-27 